\title{
Pleasing the Emperor: Revisiting the Figured Chinese Manuscript of Matteo Ricci's Maps
}

\author{
Cheng Fangyi \\ Sun Yat-Sen University \\ chengfangyi@gmail.com
}

\begin{abstract}
Aside from John Day's important survey of the figured manuscript copies of Matteo Ricci's map, there has been little investigation of the reasons they were made, the sources of their content or how they circulated. Key to understanding these maps is the text Zhifang waiji [職方外紀] (1623) edited by Giulio Aleni and Yang Tingyun. This text was actually the work of Diego de Pantoja and Sabatino de Ursis in Beijing, composed on the orders of the Wanli emperor. At the same time, a figured manuscript copy of Ricci's map was composed, which was copied by other scholars in Beijing and circulated at court. These efforts, however, were largely aimed at pleasing the Wanli Emperor rather than impressing the literati with the extent of Jesuit knowledge.
\end{abstract}

\section{Keywords}

Ming dynasty - Matteo Ricci - world maps - cartographic politics - Kunyu wanguo quantu - Giulio Aleni - Yang Tingyun - Diego de Pantoja - Sabatino de Ursis - Wanli Emperor

Recent research regarding the Jesuit mission in China challenges older elitecentered narratives by emphasizing the importance of addressing to the laity of the Jesuit missionaries. ${ }^{1}$ In terms of Jesuit cartography, a similar question can be asked: who did the Jesuit cartographer address? With Matteo Ricci (1552-1610), the traditional answer has been the Confucian literati or

1 See Liam Brockey, Journey to the East: The Jesuit Mission in China, 1579-1724 (Cambridge: Harvard University Press, 2007).

(C) CHENG FANGYI, 2019 | DOI:10.1163/22141332-00601003

This is an open access article distributed under the terms of the prevailing CC-BY-NC license at the time of publication. 
scholar-officials. However, at least in the case of the figured manuscript maps copied from Ricci's printed version, the cartographers were neither addressing the elite nor the laity but the emperor himself. Adding figures to Ricci's map directly responded to the desires of the throne, suggesting that ties between the mission's cartographical projects and conceptions of empire closely associated with the emperor began during the late Ming (1368-1644) rather than the early Qing dynasty (1644-1912).

As part of his mission in China, Ricci worked with Chinese collaborators on six editions of Chinese world maps in different cities, such as Zhaoqing, Nanjing and Beijing. Among these world maps, the Kunyu wanguo quantu [坤輿萬國全圖, “Map of the Myriad Countries of the World”] is the most wellknown and widely circulated. The Kunyu wanguo quantu circulated in both the woodblock printed version and in a hand-drawn manuscript version. ${ }^{2}$ The printed version was first engraved by Li Zhizao (李之藻, 1565-1630) in Beijing and later reprinted several times. Compared to the woodblock printed versions of Matteo Ricci's famous map, the most distinctive aspect of the hand-drawn manuscript versions are their depictions of animals, marine creatures and ships. Seven known copies of such manuscript maps survive. Their origin, however, remains unclear, and so does their audience. Where did these maps come from, and why were they made? By exploring the links between the figures on the manuscript maps and the creation of the text Zhifang waiji [職方外紀, “Records of Foreign Lands"], this paper presents a plausible theory to answer why, when and how these figured manuscript maps were made.

Before 2016, six figured manuscript copies of Matteo Ricci's maps were known to be extant. These are all apparently based on Ricci's 1602 printed edition of the Kunyu wanguo quantu. John Day listed copies in the National Library of China (Beijing), the New Bedford Whaling Museum, the Kitamura Collection (Osaka), the Nanjing Museum (reproduction in the Palace Museum), and Seoul National University, as well as one lost copy formerly owned by G. Nicolas, a French wine merchant in Beijing in the 1930s. ${ }^{3}$ Additionally, in 2016, another copy of two panels were found in a garage and initially auctioned

2 On Matteo Ricci's Chinese world maps, see among many studies, Theodore Foss, "La cartografia di Matteo Ricci," in Maria Cigliano, Atti del convegno internazionale di studi ricciani, Macerata-Roma (Macerata: Centro Studi Ricciani, 1984), 177-95; Huang Shijian and Gong Yingyan, Li Madou shijie ditu yanjitu [Study on Matteo Ricci's World Map] (Shanghai: Shang hai gu ji chu ban she, 2004); Natasha Reichle, China at the Center: Ricci and Verbiest World Maps (San Francisco: Asian Art Museum, 2016).

3 John D. Day, "The Search for the Origins of the Chinese Manuscript of Matteo Ricci's Maps," Imago mundi 47 (1995): 94-117. 
by Kaminski. ${ }^{4}$ Among the seven copies, three of them are preserved as intact with six panels (Nanjing copy), eight panels (Seoul copy) or ten panels (Kitamura copy). The Nicolas copy was also intact, but its present location is unknown and only a low-resolution monochrome reproduction is available. The Beijing and the New Bedford copies each have only one panel, four and three respectively. Although the seven copies are rather similar, these manuscripts can still be divided into two groups. Group one consists of the maps that originally consisted of six panels, including the Beijing, New Bedford, Kaminski, Nicolas and Nanjing copies. All but the last of these are thought to have been made before 1644. Group two includes the Osaka and Seoul copies, dated 1708 and 1768 respectively (Figure 2.1). The differences between them are not only the panel numbers, but also the cartographic details. Generally speaking, the eighteenth-century maps in the second group more faithfully followed the printed 1602 map of Kunyu wanguo quantu, with far fewer changes and copying errors in the text and cartography. ${ }^{5}$ The figures of ships and sea creatures as well as the depiction of the southern Pacific Ocean are the major differences between the two groups.

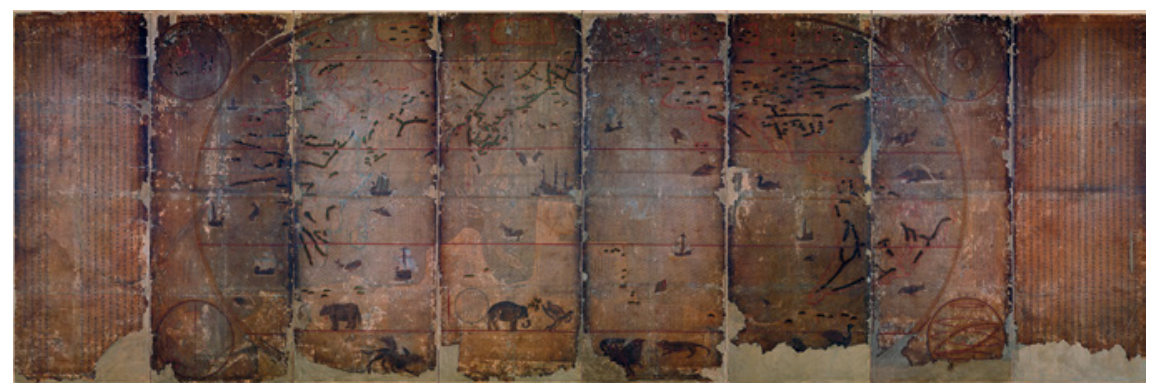

FIGURE 2.1 Manuscript copy of Matteo Ricci's 1602 map Kunyu wanguo quantu (A Map of the Myriad Countries of the World), in Seoul National University Museum, Korean SEOUL NATIONAL UNIVERSITY MUSEUM 2018

4 The Kaminski Auction copy sold at Christie's in 2017 see "Valuable Books and Manuscripts," sale 14299, July 12, 2017, http://www.christies.com/lotfinder/Lot/ricci-mateo-1552-1610-kunyu-wanquo-quantu-a-6089403-details.aspx, accessed November 30, 2017.

5 Pasquale d'Elia, William Hung, Minako Debergh and John Day all notice the cartographic and textual errors in the Nanjing copy, thought to date from the 1670 . Pasquale d'Elia, $I l$ mappamondo Cinese del P. Matteo Ricci, S.J. (Rome: Vatican Library, 1938); William Hung, "On Matteo Ricci's World Maps," in Hong Ye lunxue ji [Collected works of William Hung] (Beijing: Zhonghua shuju, 1981), 174-78; Minako Debergh, "La carte du monde de P. Matteo Ricci (1602) et sa version coréenne (1708) conservée à Osaka," Journal asiatique 274 (1986): 417-54; Day, "The Search for the Origins," 94-117. 
The additional preface on the final panels of the second group makes it clear that these were made by a copyist from the Joseon imperial court who based them on a copy given by Johann Adam Schall von Bell (1592-1666) to Crown Prince Sohyeon of Joseon dynasty when he was in Beijing as a hostage from 1644 to 1645 . Sohyeon later brought this copy back to Korea. ${ }^{6}$ The information regarding the copyist and the dates of the first group remains unclear. John Day, Huang Shijian (黃時鑒) and Gong Yingyan (壟纓晏) speculate the copyists of the maps in the first group should be Chinese artists basing on the artistic style of those figures and the reverse swastika added on the flags of the ships. ${ }^{7}$ Hong Weilian (William Hung, 1893-1980) also came to a similar conclusion. ${ }^{8}$

Regarding the "parent copy" of the figured manuscript maps, the questions raised by scholars usually concern who added these figures and at what time. William Hung, Minako Debergh, John Day, Huang Shijian and Gong Yingyan have put forward various but inconclusive theories as to who added the figures, suggesting Matteo Ricci himself, the eunuchs in the Ming palace, Schall von Bell, or an anonymous Chinese working with the Jesuits. ${ }^{9}$ Meanwhile, the broader question of why and how figures were added to the manuscript maps in the first place has received little attention. If Matteo Ricci added these figures by himself, why he didn't add them in the beginning on the woodblock like Ferdinand Verbiest did later in 1674 ? If he or other people added the figures later, what made them suddenly decide to add these figures? Who was the audience of the figured manuscript maps?

\section{Figures and the Zhifang Waiji}

Key to the answer is a 1623 book, the Zhifang waiji (Records of Foreign Lands) by the Italian Jesuit Giulio Aleni (1582-1649) and the Hangzhou literatus Yang Tingyun (杨廷筠, ca. 1560-1627). In the figured manuscripts of Kunyu wanguo quantu, eight different kinds of land animals are depicted in Terra Australis, and more than a dozen sea creatures and several ships appear in the ocean.

6 Debergh "La carte du monde," 417-54; Day "The Search for the Origins," 100. Huang Shijian and Gong Yingyan, however, argue the Seoul copy should be earlier than the Kitamura copy without giving specific dating information of the two copies. Huang Shijian and Gong Yingyan, Limadou shijie ditu, 147-55.

7 Day, "The Search for the Origins," 94-117; Huang and Gong, Limadou shijie ditu, 155.

8 Hung, "On Matteo Ricci's World Maps," 174-78.

9 Day, "The Search for the Origins," 108-10; William Hung, "On Matteo Ricci's World Maps," 174-78; Huang Shijian and Gong Yingyan, Limadou shijie ditu, 155 . 
A number of these can also be found in the Zhifang waiji. Aleni's and Yang's book has five chapters (juan 卷) with six maps attached. The first four chapters are about the four continents (Asia, Europe, Africa and America), while the last chapter is about the oceans, including the name of the oceans, seas, islands, sea creatures, ships and so forth. The records about the land animals are mainly in the first four chapters, and the information regarding the "monstrous" fishes and ships are in the final chapters. In the book's six maps, however, only two ships and one sea creature appear.

The manuscript versions of the Ricci map thus put the ships and creatures from the Zhifang waiji onto the map. Among the eight kinds of land animals in the Terra Australis of the manuscript maps, six of them have related texts in the Zhifang waiji. From the left to right, the animals were a rhinoceros, dragon (winged creature), elephant, sloth, Patagonian "sú" (succarath), crocodile, lion and greater rhea. All of these, except the dragon and the su had a corresponding text in the Zhifang waiji. ${ }^{10}$ The rhinoceros is introduced in the first chapter under the entry for India. ${ }^{11}$ The elephant can be found in chapter one under both India and Java. ${ }^{12}$ The sloth and greater rhea are in chapter four under Brazil and Peru. ${ }^{13}$ The lion appears in chapter three under the general introduction of Africa. ${ }^{14}$ Finally, a description of crocodile can be found in chapter five under the "sea creatures." 15

Several details in the texts correspond to the figures on the manuscript maps. The elephant is mentioned twice in the Zhifang waiji, once as the Indian elephant and the other as the Javanese white elephant. ${ }^{16}$ In the Nanjing copy of the group one manuscripts, the elephant is presented in white color, but in the Seoul copy of group two, the elephant's color is not white but grey like the other animals. Similarly, in chapter four of the Zhifang waiji, the greater rhea is

10 On the $s u$, see Day, "The Search for the Origins," 106. A text about the sú can be found in Ferdinand Verbiest, Kunyu tushuo 2 (Beijing, 1674). It was originally described by André Thevet in Les Singularitez de la France antarctique (Paris: Maurice de la Porte, 1557), and popularized in his La Cosmographie Universelle (Paris: G. Chaudière, 1575).

11 Giulio Aleni and Yang Tingyun, Zhifang waiji jiaoshi [职方外纪校释 “Collation and Annotation on the Records of Foreign Lands"], ed. Xie Fang (Beijing: Zhonghua shuju, 1996), 41.

12 Aleni and Yang, Zhifang waiji, 40, 61.

13 Aleni and Yang, Zhifang waiji, 126, 123.

14 Aleni and Yang, Zhifang waiji, 105-6.

15 Aleni and Yang, Zhifang waiji, 149-50. The "sea creature" section introduces the "Lawaerduo" [剌瓦而多], a kind of saltwater crocodile.

16 Aleni and Yang, Zhifang waiji, 40, 61. 
introduced under Peru with the cattle-hoof feet. ${ }^{17}$ In the Kunyu wanguo quan$t u$, Matteo Ricci also introduces a similar animal. ${ }^{18}$ Even though Ricci mentions, "its feet are like the horse's," in the Seoul copy, the greater rhea clearly has two cattle hooves corresponding to the description "its feet are like cattle hooves" in the Zhifang waiji, instead of horse hoof. Finally, the sloth in chapter four under Brazil includes the description,

The state has an animal named Lanmian (懒面, literal “lazy face”), which is very lazy. Its claws are like human fingers, and its bristles are like horse's. It can't walk because its belly reaches the ground, and can only move less than one hundred steps in one month. It likes eating leaf. When it climbs up the tree to get it, it takes two days. It takes the same amount of time when it climbs down. There is definitely no way to make it fast. ${ }^{19}$

In both groups of figured manuscript maps, the tree and leaves were vividly depicted for the sloth, and its claws were also portrayed as human fingers.

Besides the land animals, the Zhifang waiji also describes seacrafts and sea creatures in its final chapter. The "seacraft" (haibo 海舶) section introduces different types of ships classified according to their sizes and functions. ${ }^{20}$ Some of the ships presented in the manuscript maps were clearly drawn directly from European printed maps, notably Abraham Ortelius's (1527-98) atlas (1570-1612), but in general they are not distinctive enough to associate with the descriptions in the Zhifang waiji. ${ }^{21}$

The "sea creature" (haizu 海族) section in the Zhifang waiji records twentytwo varieties, including two kind of sea birds. A large part of the text can be traced back to volume twenty-one of Olaus Magnus's (1490-1557) Historia de gentibus septentrionalibus ["History of the northern people"] (1555), "De piscibus monstrosis" ["The monstrous fishes"]. Although the sea creature figures were probably drawn by a Chinese artist, some of them can still be recognized as derived from Ortelius's map of Iceland $\left(15^{8} 7\right) \cdot{ }^{22}$ Some, however, appear to be drawn based purely on the text. The northernmost fish figure on panel one

17 Aleni and Yang, Zhifang waiji, 123 .

18 The text is placed near Malaysia in the fourth panel of the 1602 edition of Kunyu wanguo quantu.

19 Aleni and Yang, Zhifang waiji, 126.

$20 \quad$ Aleni and Yang, Zhifang waiji, 156-57.

21 Day, "The Search for the Origins," 106-7.

22 Gudbrandur Thorlaksson and Andreas Vedel, "Islandia" in Abraham Ortelius, Théâtre de l'Univers (Antwerp: Christopher Plantin, 1587), 103. Day, "The Search for the Origins," $105^{-6 .}$ 
in the Nanjing copy, which can also be found in the Seoul and Kaminski auction copies, has a fishtail and a dorsal fin combined with eight sharp spines. Its protruding and long head and its huge mouth with more than a dozen teeth below the head make this figure particularly peculiar. No similar figure of sea creatures appears in Ortelius, Magus, or other contemporary works on the sea creatures. This figure, however, largely corresponds with the description of one sea creature recorded in the Zhifang waiji. About this sea creature, it says,

One fish is huge with the longitude of more than 31.1 meters and breadth of more than 3.1 meters. Its eyes are as large as 62.6 centimeters, and its head has the height of 248.8 centimeters. Its mouth is in the below of its abdomen, and has twenty-two teeth. Each tooth has the diameter of 31.1 centimeters. Its mentomeckelian bone is also as long as 155 to 186.6 centimeters. It was once flushed to the shore during the strong wind. ${ }^{23}$

Following details such as the height of the head, the mouth in the abdomen area and thirty-two big teeth in the text, the Chinese artist clumsily drew a protrusion on top of the fish shape to meet with the details in the text.

\section{The Birth of the Zhifang Waiji}

Although the Zhifang waiji was edited and compiled by Giulio Aleni and Yang Tingyun in 1623, the major texts in that book were actually not produced by them or at that time. Most of the of Zhifang waiji was developed a decade earlier at the Ming imperial court by two Jesuit missionaries, Diego de Pantoja (1571-1618) and Sabatino de Ursis (1575-1620). In 1612, after Matteo Ricci's death, the court received two maps from Fujian from a eunuch in charge of tax collections there. ${ }^{24}$ The Wanli Emperor $\left(1563^{-1620}\right)$ was interested in the content of the maps, so he asked Pantoja and Ursis to view them and translate the information for him. On September 26, 1612, the two Jesuits viewed the two maps and soon wrote a memorial to the throne, explaining that they were "two printed sheet maps" [印版圖畫] and part of a set of four maps sent from Europe. They asked the emperor that if they could add the two missing

23 Aleni and Yang, Zhifang waiji, 149. The units in Chinese are chi (尺) and zhang (丈). The conversion into meters and centimeters is based on the research of Wu Chengluo (吴 承洛), Zhongguo duliangheng shi [中國度量衡 “History of Chinese weights and measures"] (Shanghai: Shanghaishudian Press, 1984), 66.

24 Aleni and Yang, Zhifang waiji, 6. 
maps, translate the whole set and compile these into a book for the emperor. They further asked the emperor if they could borrow a book from the palace library, a gift from Matteo Ricci, to help their translation project, emphasizing the significance of such a book for the emperor. In the end of this memorial, they stated that they had only split the maps and translated some of the place names for the emperor. ${ }^{25}$

A couple of months later, the emperor again sent the two original maps to them, requesting a more detailed translation. Apparently, the emperor showed no interested in their proposal of compiling the translations as a book, nor did he lend them the book they requested. Pantoja and Ursis sent another memorial, explaining that they copied the original two maps and added another two pieces - the map of China and the map of Southwestern States (西南方國) 一 to create four scrolls with Chinese explanations. They also wrote articles on the different states, which they attached below the maps. All the four scrolls with the original two maps and other gifts were sent back to the emperor. According to Pantoja and Ursis, in their second memorial, "large paragraphs were omitted in the translated texts" because of their "ignorance" and lack of reference material. ${ }^{26}$ Again, they asked for the book donated by Ricci to the palace library as a reference. No record survives of any interest from the imperial court requesting more information about the two maps.

The project of compiling their translations into a book may have been abandoned by Pantoja and Ursis, but they nevertheless used some of this work for a subsequent project, at least according to Ricci's confident Li Zhizao (15651630). In Li Zhizao's preface to the Zhifang waiji, he mentions Pantoja and Ursis's involvement in the translation of the two maps obtained by the imperial court. ${ }^{27}$ Although Li's preface recounts some of the events in Pantoja and Ursis's memorials, he makes errors about important details. According to Li, one of the five continents was missing in the two maps. But according to Pantoja and Ursis's memorial, fully half of the maps were missing. Li also did not know that they not only translated the original two maps but also added two maps and sent all the translations of the four maps to the throne. After mentioning this issue, Li Zhizao continued,

25 Aleni and Yang, Zhifang waiji, 17.

26 Aleni and Yang, Zhifang waiji, 18.

27 Li Zhizao's preface is arranged as the third preface in the Zhifang waiji jiaoshi edited by Xie Feng. But in the Tianxue chuhan (天學初函) edition and Min (閩) edition of Zhifang waiji published in the end of Ming dynasty, it appears as the first preface among several prefaces. 
They (Pantoja and Ursis) then also drew another eight-panel screen map. They recorded what they have heard and seen, added the local customs and products, and explained with detailed regular script. I went to Beijing in the year of Jiayin (1614) to take office, and had the fortune to view it. This map was not finished for a long time. At that moment when Pantoja and Ursis were expelled from the capital, they brought it to the Office of Transmission, but it was not accepted. Then they brought it to the Great Ming Gate and left after kowtowing. Today it is still in the Central City Censorate. Pantoja and Ursis, however, passed away soon on their way. Their original text was copied and circulated by the literati in the capital, but like the fragmented jade and lost bead, the copies are not consistent. In the summer of this year, my friend Yang Zhongjian (Yang Tingyun) and the westerner Master Ai (Giulio Aleni) edited and compiled it, adding some content. ${ }^{28}$

Li's statement suggests that Pantoja and Ursis did indeed subsequently draw an eight-panel screen map with interpreting texts attached to it. In the same paragraph of the preface, before mentioning Pantoja and Ursis's translation and map, Li mentions his own translation and printing of Kunyu wanguo quan$t u$ and another copy by the eunuchs. Then he said Pantoja and Ursis had "also drawn another eight-panel screen map." This eight-panel screen map should have been another copy of Kunyu wanguo quantu, but Pantoja and Ursis "recorded what they have heard and seen, added the local customs and products, and explained with detailed regular script."

Li Zhizao saw Pantoja's and Ursis's map himself in 1614 when he was in Beijing, but it was not finished at that time. Later because of the Nanjing incident and trials between 1616 and 1618, Pantoja and Ursis were expelled from Beijing. They wanted to send the map to the court but it was not accepted. Eventually they had it left in front of the Great Ming Gate. They went to Macao and died there. What Li called the "original text" (diben 底本) should be the text accompanying the map left in Beijing by Pantoja and Ursis, most likely including the translations they had earlier made for the emperor. Later the original text was copied and circulated among the literati at Beijing. Only then did Giulio Aleni and Yang Tingyun edit and compile it as part of the the book Zhifang waiji.

Because it is clear that Pantoja and Ursis were the ones who "added the local customs and products" to Ricci's map in its manuscript version and because the content of the Zhifang waiji, largely composed by Pantoja and Ursis, corresponds closely to the figured manuscript map of Kunyu wanguo quantu, it

28 Aleni and Yang, Zhifang waiji, 6. 
is reasonable to suggest that Pantoja and Ursis were the people who drew the original copy of the figured manuscript of Kunyu wanguo quantu. The reason they added the figures was an attempt to leverage the emperor's deep interest in the two maps from Europe, translated by Pantoja and Ursis and unlike Ricci's map containing images of creatures. Before receiving the two European maps from Fujian area, the Wanli Emperor had already seen the woodblock printed versions of Kunyu wanguo quantu ${ }^{29}$ The emperor requested the translation for the two maps from Fujian twice, while at the same time rejecting Pantoja and Ursis's proposal of compiling a more substantial book about other maps. So there must have been on these maps something different from Matteo Ricci's version that triggered the emperor's special interest.

According to Pantoja and Ursis's memorials, the two printed maps obtained by the emperor were from Europe and belonged to a set of four maps. Although they told the emperor that they added the map of China and the map of Southwestern States as the other two pieces in the set, the two maps from Fujian were most likely from the set of four maps of the four continents, Asia, Africa, Europe and the Americas. In the second half of the sixteenth-century and the whole seventeenth-century, sets of four maps showing the four continents became very popular in Europe, repeatedly appearing in household inventories of merchants and gentry. ${ }^{30}$ Pantoja and Ursis added the maps of China and Southwestern States most likely because they did not have copies of the other two maps in the set and could not access them from the text Ricci had donated to the imperial library. When the maps did not engage the emperor's interest, Pantoja and Ursis decided to drawn another copy of Kunyu wanguo quantu and add the figures to it.

One possible source of the two European maps from is Giacomo Gastaldi (1500-c.1565), who not only made a large and undated ten-sheet woodcut world map with the title Cosmographia universalis, on which the ships and sea creatures in the ocean and land animals including the dragons in the Terra Australis, but also produced a now lost set of four maps of the four continents. ${ }^{31}$ Besides employing the two maps from Europe, Pantoja and Ursis also drew some figures based on their translated text, such as the northernmost fish figure near the east coast of north America discussed earlier, to build correlation between their translations and the manuscript map.

\footnotetext{
29 William Hung, "On Matteo Ricci's World Maps," 174-75.

30 John Brian Harley and David Woodward, eds., History of Cartography 3:1 (Chicago: University of Chicago Press, 2007), 787 .

31 Harley and Woodward, History of Cartography, 3:1, 784-86.
} 


\section{Conclusion and Discussion}

Building on the plausible theory that Pantoja and Ursis added the figures onto the map originally because of the Ming emperor's interest helps explain the process of mapmaking and circulation of these maps. As the emperor's interests became clearer, adding the figures to the map as a supplement became their main purpose. Their figured manuscript version of the printed 1602 Kunyu wanguo quantu, left in Beijing after 1616, helped generate interest in their corresponding text, which was copied by the Chinese artists and circulated among the Ming literati and later edited and compiled into the book Zhifang waiji. This now lost manuscript map should be the "parent copy" of the first group of the six-panel figured manuscript maps, including the Nanjing, Beijing, Kendall Whaling Museum and Nicolas copies. A culture of copies emerged in Beijing, largely because of the emperor's interest, which produced a number of divergent versions of both the text and the map.

The Korean copies, which came through the mediation of Schall von Bell, open up further questions. When Pantoja and Ursis left Beijing, they possibly brought their "original copy" - a draft most likely using a printed 1602 Kunyu wanguo quantu with the figures added by hand-to Macau. This map would have been available to Schall von Bell before he left Macao for Beijing in 1622. He possibly made his own copy with some changes and brought it to Beijing, but it is also possible that he employed one of the copies circulating in Beijing. Schall von Bell's changes (or perhaps even Pantoja's and Ursis's) would have been made to reduce the religious implication of the map, such as the two big ships in the South Pacific Ocean with the masts and spars forming the sign of the cross and St. Andrew's cross on the "original copy." This would have been a result of the Nanjing church incident, which had resulted in trials and expulsions of Jesuits for not following imperial rites. ${ }^{32}$ One of these new copies was given to Crown Prince Sohyeon by Schall von Bell, which in turn led to the Seoul and Kitamura copies. ${ }^{33}$ Schall von Bell's copy also explains why the maps in the second group more faithfully followed the printed 1602 map of Kunyu wanguo quantu, with far less copying errors in text and cartography that had emerged as the maps circulated at court.

When Ferdinand Verbiest worked on his famous Kunyu quantu (坤輿全圖, "Complete Map of the World," published in 1674), as Schall von Bell's assistant, he too would have been aware of the figured manuscript map copy of Kunyu wanguo quantu. This was the most likely inspiration for his own addition of the

\footnotetext{
32 Debergh, "La carte du monde," 417-54.

33 Debergh "La carte du monde," 417-54; Day "The Search for the Origins,"100.
} 
figures of ships, land animals and sea creatures to his map for the Kangxi Emperor (r.1661-1722). ${ }^{34}$ In both his map the Kunyu quantu (1674) and his geography text the Kunyu tushuo (c.1672), Verbiest followed Schall von Bell in further reducing the possible controversial religious and mythical content, notably removing the dragon figure ${ }^{35}$ (Figure 2.2).

The appearance and circulation of the figured manuscript map of Kunyu wanguo quantu shows an increasing tightening of the links between Jesuit cartography in China and the imperial throne, a process in sharp contrast to Jesuit missionaries in the field who were trying to address the laity. In this sense, Jesuit cartography as practiced here followed a very different strategy than the broader project of translating scientific and mathematical works, specifically trying to engage the emperor through his own interest in creatures like those that could be found in the classic Shanhai jing [山海經]. Pantoja and Ursis tried to impress the emperor by making a new world map that included

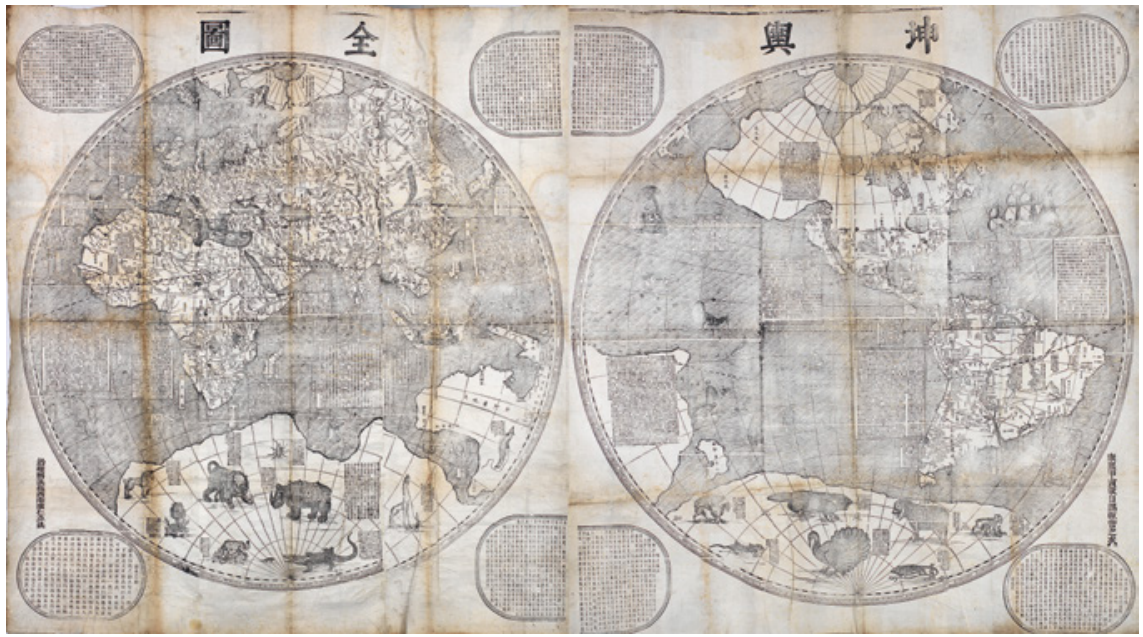

FIGURE 2.2 Part of the Printed Map of Ferdinand Verbiest's 1674 world map, Kunyu quantu, in Hunterian Museum

THE HUNTERIAN, UNIVERSITY OF GLASGOW 2018

34 The appearance of the "su" in the Kunyu quantu can support this statement. If Verbiest only had access to Zhifang waiji, the "su" should not appear on his map because $s u$ is not recorded in the book. But the su still appears in the Kunyu quantu, and Verbiest added a description about su in his book Kunyu tushuo (Commentaries on the World Map) published also in 1674, the second volume of which is largely based on the Zhifang waiji.

35 Regarding the revisions made in the Kunyu tushuo, see Shen Yi'an, Nan Huairen de Kunyu tushuo yanjiu [Research on the Kunyu tushuo by Ferdinand Verbiest] (Master thesis, Fo Guang University, 2011). 
figures, aware of his interest in the maps transmitted from Fujian. When they were expelled from Beijing, they most likely saw this map as a final way to save the Jesuit mission and its presence at court. Schall von Bell followed a similar strategy, and the figured manuscript copy not only triggered the interest of the imperial family in Korea but also helped by way of Verbiest to set up the Jesuit cartographical project during the Qing dynasty, with its close links to the representational strategies and mapping projects directed by eighteenth-century emperors. While this transition to an imperial strategy is evident in the work of Schall von Bell and Verbiest, it was Pantoja and Ursis who pioneered it in the immediate aftermath of Ricci's death. 